\title{
Diplomacy : la cliopolitique selon Henry Kissinger. Partie 3
}

Jean-Yves Haine

\section{OpenEdition}

\section{Journals}

Édition électronique

URL : http://journals.openedition.org/conflits/890

DOI : $10.4000 /$ conflits.890

ISSN : $1777-5345$

Éditeur :

CCLS - Centre d'études sur les conflits lilberté et sécurité, L'Harmattan

Édition imprimée

Date de publication : 15 octobre 1995

ISSN : 1157-996X

\section{Référence électronique}

Jean-Yves Haine, « Diplomacy : la cliopolitique selon Henry Kissinger. Partie 3 », Cultures \& Conflits [En ligne], 19-20 | automne-hiver 1995, mis en ligne le 04 mars 2003, consulté le 30 mars 2021. URL : http://journals.openedition.org/conflits/890 ; DOI : https://doi.org/10.4000/conflits.890

Ce document a été généré automatiquement le 30 mars 2021.

Creative Commons License 


\title{
Diplomacy : la cliopolitique selon Henry Kissinger. Partie 3
}

\author{
Jean-Yves Haine
}

Contrairement à ce qu'estimait Kissinger, la modération n'était donc pas le résultat du Concert, elle était au contraire l'un de ses fondements. La paix reposait sur l'équilibre politique, et la prudence seule ne pouvait la garantir. La faillite du système intervient dès le moment où ses bases de cette modération commencent à s'effriter. L'homogénéité politique des acteurs se dissout, la force des liens religieux et monarchiques s'amenuise, la guerre redevient une politique acceptable et la rivalité resurgit. L'équilibre politique et la communauté idéologique constituent donc les véritables facteurs de la paix, tandis que le le Balance of power marque sa rupture. En un mot, pour reprendre une formule lapidaire, c'est la paix qui a maintainu le concert, et non le concert qui a favorisé la paix ${ }^{1}$.

En définitive, Kissinger a commis, nous semble-t-il, une double erreur. D'une part, il a exagéré l'influence du Balance of Power dans l'histoire des relations internationales, de l'autre, il s'est mépris sur les causes réelles de la paix, non seulement en 1815, mais plus encore au XXème siècle. Tout d'abord, sa confusion est manifeste entre le Balance et de Concert, qui sont des notions presque synonymes chez lui, alors qu'elles sont contradictoires et reposent sur des bases diamétralement opposées. Parce que la modération ne fut qu'une méthode de sa diplomatie et non son fondement ${ }^{2}$, parce qu'il ne mit en œuvre qu'un Balance et non un Concert, la politique de Kissinger ne contribua que dans une très faible mesure à la stabilité mondiale. Ses effets modérateurs restèrent fragiles et temporaires, et furent largement surestimés ${ }^{3}$. La paix, pour autant qu'on puisse évoquer ce terme tant les conflits périphériques furent nombreux, ne fut donc ni le résultat d'une structure qui n'exista que dans son esprit, ni un effet du Balance of Power amorcé depuis le containment, mais principalement un produit de la dissuasion nucléaire ${ }^{4}$. Le Balance of Power n'est pas une structure opérante mais seulement un cadre d'affrontements privilégiant le secret, la duplicité et la liberté de manœuvre. On comprend aisément les faveurs de Kissinger pour ce type de diplomatie mais son erreur fut de croire qu'en privilégiant les rencontres au sommet et les contacts personnels, il réussirait à changer le cours des évènements. Sa diplomatie 
ne modifia guère l'attitude des grandes puissances, et n'eut aucun effet sur la périphérie. Au contraire, comme l'ont démontré les avatars de la détente, le comportement des acteurs détermina le contenu de sa diplomatie ${ }^{5}$. Son néoréalisme basé sur la diplomatie personnelle resta lettre morte. En négligeant les "sources"6 $\mathrm{du}$ comportement soviétique, et en rejettant les tentatives pour les modifier, Kissinger pratiqua une version très réductrice du containment, centrée principalement sur le maintien du statu quo. Il fut sans doute un dirigeant bien moins "créateur" qu'Acheson. Rien ne fut jamais entrepris qui put favoriser un changement dans les intentions soviétique. La guerre froide était une équation constante dont il ne fallait surtout pas modifier les variables. Avec Kissinger à la Maison-Blanche, la paix était plus improbable que jamais et la guerre était toujours aussi impossible.

Ce conservatisme excessif procède en réalité d'une seconde erreur plus radicale. Sa conception trop étroite de la légitimité s'avère en effet erronée et son application fut anachronique. Le Concert de 1815 était fondé, on l'a vu, sur la communauté d'intérêts de ses principaux acteurs. L'historicisme rankéen de Kissinger, qui privilégiait le sommet au détriment de la base, et instaurait un cloisonnement factice entre la politique étrangère et la politique intérieure, engendra une confusion entre les causes et effets du Concert de 1815. En voulant reproduire un modèle et appliquer des méthodes diplomatiques historiquement dépassées, Kissinger ignora totalement les nouvelles réalités de la politique internationale. Si sous Metternich la légitimité était monarchique, dès la fin du 19ème siècle, elle devint démocratique. Plus les sociétés devenaient responsables, plus le modèle kissingérien devenait anachronique. Comme l'a sanctionné la catastrophe de la Première guerre mondiale, l'ordre ne pouvait plus se limiter à un accord entre dirigeants, mais devait aussi inclure les conditions internes ${ }^{7}$. Comme l'illustra la décennie 1980, la paix n'est pas seulement un sous-produit de l'ordre, mais plus fondamentalement un résultat de la justice. Parce qu'il ne s'intéressa qu'aux seules relations entre dirigeants, parce qu'il a toujours négligé les réalités économiques et sociologiques qui sont à la base de la politique, parce qu'en un mot il s'est contenté d'étudier la forme au détriment du fond, il est passé à côté de la seule leçon pertinente que l'on pouvait déduire de 1815 : le concert ne se dicte pas d'en haut mais s'établit par le bas, la légitimité ne se décrète pas mais se construit. Et plus que jamais aujourd'hui, l'ordre inclut la justice.

1989 et la justice

D'essence conservatrice, le concert de 1815 ne résista pas aux mouvements sociaux internes, et la paix monarchique succomba sous l'effet des révolutions de 1848 . Les chefs d'Etats ont pu imposer le statu quo pendant un temps limité, mais ils n'ont pu s'opposer à la force des revendications révolutionnaires et à la montée des nationalismes. Le réalisme historiciste de Kissinger, basé sur l'anarchie structurelle, sur la prédominance du chef de l'Etat, et sur la primauté de la politique étrangère, ne pouvait qu'ignorer les fondements sociologiques et politiques qui ont été à la base du Concert et de sa rupture. Sa lecture apparaît donc déjà bien limitée pour le 19ème siècle, mais depuis l'émergence de la démocratie à l'aube de ce siècle, elle nous semble totalement erronée. De manière plus générale, les paradigmes réalistes, parce qu'ils considérent que le dilemme de sécurité est un donné et non un construit ${ }^{8}$, parce qu'ils posent l'immuabilité de la forme étatique ${ }^{9}$ au détriment de la dynamique des sociétés ${ }^{10}$, sont par leur définition même hermétiques aux changements et aux évolutions de la vie politique internationale. En estimant que l'anarchie est la seule structure qui s'impose aux Etats, ils décrétent dans le même temps que ce dernier n'est ni susceptible 
d'évoluer ni de modifier à son tour l'environnement dans lequel il évolue. De ce fait, les évolutions sociétales et transnationales sont systématiquement écartées. Or, force est de constater que les Etats à l'heure actuelle n'ont plus grand chose en commun avec ceux qui ont signé le Traité de Westphalie et qu'aujourd'hui le système international n'est plus celui de 1648. Il est donc essentiel de réintroduire les sociétés dans la politique internationale, de partir d'en bas pour arriver en haut, et non l'inverse. La décennie 1980, plus encore que celle de 1815, illustrent clairement cette nécessité de changer de perspectives et révèlent les limites manifestes de l'analyse réaliste en général et de l'approche kissingérienne en particulier.

Kissinger se contente en effet d'une appréhension géopolitique de la fin de la guerre froide, en soulignant la victoire de la force reaganienne sur la faiblesse soviétique. Fidèle à sa conception rankéenne, la chute du Mur de Berlin se limite à une histoire de diplomates et à son aspect le plus visible, le dialogue Reagan-Gorbatchev. Il n'est pas lieu ici de refaire l'histoire de la fin de la guerre froide, mais de souligner brièvement les insuffisances des explications et l'incohérence des paradigmes néoréalistes avant d'ébaucher une autre interprétation concurrente des changements de 1989. En premier lieu, le Balance of Power ne peut constituer en aucun cas la seule grille d'analyse pertinente pour justifier la nouvelle pensée politique de Gorbatchev dès le milieu des années $1980^{11}$. Si la recherche de puissance induite par la structure anarchique constitue la donnée permanente du système international, alors l'abandon par l'Union soviétique de son glacis principal de sécurité en Europe de l'Est contredit les résultats attendus de la théorie (néo)réaliste ${ }^{12}$. La distribution de puissances entre les deux Grands ne permet d'expliquer précisément ni le déroulement de la guerre froide, ni le changement de comportement de Gorbatchev ${ }^{13}$. Pour justifier la réorientation radicale de Moscou dès 1985, l'analyse doit sortir du cadre réaliste. Il faut renverser le schéma d'analyse classique, et considérer d'abord les développements internes, les changements de conceptions dans le domaine de la sécurité, la dynamique des enjeux sociaux, et la force des idées politiques et des manifestations culturelles, et analyser ensuite leurs conséquences sur le système international.

Dans le domaine de la sécurité, il faut relever tout d'abord l'importance des échanges et des réflexions entre l'Est et l'Ouest menées au sein de la CSCE. Entre la nouvelle pensée politique de Gorbatchev et les conceptions sur la sécurité commune émises au sein de la Commission Palme, notamment par Egon Bahr, les similitudes sont loin d'être fortuites. Succintement, dans les cercles de réflexions stratégiques en Europe particulièrement en Allemagne de l'Ouest, mais aussi parmi les proches de Gorbatchev, une conception commune selon laquelle il ne pouvait y avoir de sécurité sans coopération mutuelle s'est peu à peu imposée à partir de la moitié des années $1980^{14}$. Il ne s'agissait pas seulement de relations interétatiques mais bien d'échanges entre experts au niveau individuels et académiques. De plus, les partis politiques allemands entretenaient des contacts étroits avec les membres de la société civile polonaise, est-allemande et soviétique et il n'est donc pas surprenant que Bonn se soit montré particulièrement enthousiaste vis-à-vis des premières réformes de Moscou, contrairement à Washington. Gorbatchev lui-même reconnut qu'il avait été fortement influencé par les travaux de la Commission Palme et qu'il s'en était inspiré pour développer son concept de maison commune européenne ${ }^{15}$. Les premières Mesures de Confiance et de Sécurité développées au milieu des années 1980 témoignent de cette prise de conscience au niveau politique et attestent que la notion de sécurité commune était devenue majoritaire en Europe ${ }^{16}$. Ceci signifie que, même dans le domaine stratégique, pourtant 
au cœur des analyses réalites, les évolutions ne sont pas uniquement dépendantes d'un rapport de forces ou d'une distribution de puissances mais qu'au contraire les idées, les conceptions et leurs échanges y jouent au contraire un rôle fondamental ${ }^{17}$. Par conséquent, il y a lieu là aussi de tenir compte de la base avant d'envisager les décisions au sommet. Sans cette démarche, on se méprend sur les fondements des conceptions de Gorbatchev et sur les effets qu'elles ont suscité à l'Ouest. Bien loin d'être une victoire de Washington, les débuts de la nouvelle politique de Moscou marquent avant tout l'adoption par Gorbatchev du concept de sécurité commune prônée par une majorité d'experts en Europe et témoignent de sa volonté d'aménager et puis de sortir du dilemme de sécurité qui gelait ses rapports avec l'Occident. C'est la conception associative et communale de la puissance qui s'est imposée, et non un effet du Balance of Power.

Il convient ensuite de souligner les travaux, préparés dans le cadre du processus d'Helsinki, du Réseau Européen pour le Dialogue Est-Ouest, dont les membres n'étaient pas des Chefs d'Etat mais des représentants de la société civile de part et d'autre du Rideau de fer. Dans son rapport de 1985, fruit d'un échange entre dissidents de l'Est et observateurs et leaders d'opinion à l'Ouest, il est rappelé l'importance et l'interdépendance des trois paniers de la $\operatorname{CSCE}^{18}$. La conviction est générale pour estimer que la sécurité en Europe repose d'abord sur le respect des libertés civiles et politiques au sein des Etats et qu'elle pourra être assurée ensuite par une confiance mutuelle entre responsables étatiques ${ }^{19}$. La sécurité en Europe était avant tout une question de sécurité individuelle au sein de l'Etat ${ }^{20}$, accessoirement une question de rapports diplomatiques entre eux. La détente si elle ne reposait pas sur des bases internes n'avait aucune chance d'aboutir. Les conclusions du Réseau Européen sont particulièrement éclairantes. Elles décrivent non seulement le processus par lequel la guerre froide prendra effectivement fin, mais constituent par ailleurs une excellente critique d'une politique limitée au sommet envisagée par les réalistes et mise en œuvre par Kissinger :

"La politique de détente, pour parvenir à des résultats durables, doit s'appuyer sur une base solide non seulement au niveau gouvernemental, mais également au sein des sociétés. Les contacts entre les populations et les activités communes entre les groupes et les individus par delà les frontières peuvent dissoudre les structures de la Guerre Froide et préparer le terrain pour une " paix chaude ». La politique officielle de détente devrait créer un cadre qui encourage le processus de « détente par le bas ».

La paix, qui plus qu'en 1815 n'était pas seulement l'absence de guerre, devait s'établir à partir des sociétés, lesquelles ne connaissent pas de frontières, elle ne pouvait pas se commander seulement depuis les Etats ${ }^{21}$. Elle doit reposer d'abord sur les conditions internes et sur la légitimité du pouvoir exercé au sein des Etats, et non sur une seule légitimité reconnue entre eux. Comme le notait Vaclav Havel: "Une paix durable ne peut être le fruit que de peuples libres. Le respect des droits de l'homme est la condition fondamentale et la seule garantie authentique d'une paix véritable".

La dernière décennie de la guerre froide fut donc marquée par bien autre chose que la simple modification d'un rapport de force. Les vidéos, les films, les émissions de Radio Free Europe, les échanges culturels et les aides économiques ont fait beaucoup plus pour la fin de la guerre froide que les missiles du SAC ou les lasers de l'IDS. Ce n'est d'ailleurs pas un hasard si à Moscou on qualifia la démocratisation à l'Est de doctrine Sinatra. L'obsession kissingérienne pour l'ordre géopolitique au détriment des 
véritables facteurs de paix l'amena par ailleurs à prodiguer des initiatives inadaptées aux nouvelles réalités internationales. En décembre 1988, il proposa au président Bush de négocier secrètement un accord avec Moscou. En échange de la promesse de Gorbatchev de ne pas s'opposer aux réformes politiques en Europe de l'Est, les EtatsUnis s'engageaient à ne pas exploiter la situation en leur faveur au détriment des intérêts légitimes de l'Union soviétique. Ce plan, qualifié de Yalta II par le Département d'Etat, fut rejeté tant à Moscou qu'à Washington ${ }^{22}$. Le Balance of Power n'explique donc pas la fin de la guerre froide, son application politique en a au contraire retardé l'échéance. ${ }^{23}$ Dès lors qu'il existe une communauté d'intérêts, ses méthodes deviennent inutiles et contreproductives ${ }^{24}$. Si dans les sociétés monarchiques, la puissance était principalement une question de ressources des gouvernements, elle se mesure désormais à l'aune du bien être social et des libertés publiques. Les méthodes et les postulats réalistes ne peuvent plus représenter la seule grille de lecture de la vie internationale et ce d'autant plus qu'on assiste à une généralisation de la paix démocratique ${ }^{25}$. Il y a bien aujourd'hui une "nouvelle" diplomatie fondamentalement différente de celle prônée et pratiquée par Kissinger ${ }^{26}$. Elle n'est plus dictée par le seul dilemme de sécurité, mais bien par les évolutions de la "société civile" ${ }^{27}$, dont la logique relève plus d'A. Smith que de Thucydide. La leçon principale de la guerre froide est qu'on ne peut séparer les affaires étrangères des conditions intérieures, la stabilité de la justice et la paix de la liberté.

Les conclusions sont donc sévères pour l'approche réaliste en général et pour sa version kissingérienne en particulier. Si les hommes d'Etats doivent être jugés non seulement par leurs actions mais aussi par les alternatives qui étaient à leur disposition $^{28}$, alors le bilan de Kissinger est particulièrement décevant. Un écrivain tchèque, un électricien polonais et un acteur d'Hollywood ont été des hommes d'Etat bien plus créateurs que Kissinger le diplomate. Comme le reconnaît plus modestement James Baker, les "gens ordinaires"29 font aussi l'histoire.

\section{NOTES}

1. . "It was peace that maintained the Concert, and not the Concert that maintained peace". Medlicott William. N., "Bismarck, Gladstone and the Concert of Europe", Greenwood Press, 1969, p. 18.

2. . "As a method of regulating international behavior and conflict, it did not generaly deter hostile political or military action. Much of the traditionnal writing on the balance of power glorifies an institution that was phlegmatic and unpredictable at best. In sum, the history of the balance of power is one of either weakness or misperceived strength". Rosecrance Richard, "A new Concert of Powers", Foreign Affairs, Spring 1992, Vol. 70, n², p. 66 et 69.

3. . "The inclination to exaggerate the success of the balance of power accompanies the disinclination to be explicit about what constitutes success. Balance of power is advertised as a producer of moderation, but its champions concede that it is a product of moderation. This came perilously close to saying that Balance of Power depends 
upon world order, rather than world order depends upon Balance of Power." Inis Claude L., "The Balance of Power Revisited", op-cit., p. 79.

4. . Waltz, qui avait toujours prétendu que la stabilité découlait de la bipolarité, reconnut que la dissuasion nucléaire joua un rôle essentiel dans la "longue paix". Voir Waltz Kenneth, "Reflections on Theory of International Politics : A Response to My Critics", in Keohane Robert O., "Neorealism and Its Critics", Columbia University Press, 1986, pp. 326-330.

5. . Le Balance n'est donc pas un mécanisme structurant, au contraire, ce sont les évolutions entre les puissances qui déterminent son contenu. C'était déjà vrai pour l'Europe du 19ème siècle : "It would be mistaken of making the balance of power the reigning principle and mechanism governing European politics. Instead of the balance of power explaining what happened in European politics, what happens in European politics explains what happened to the idea of the balance of power". Schroeder Paul, "The Nineteenth Century System : The Balance of Power or Political Equilibrium", opcit., p. 141.

6. . Par référence au texte fondateur du containment de Kennan George, "The sources of the Soviet Conduct", Foreign Affairs, July 1947, Vol. 25, n4, pp. 566-582. Il écrivit plus tard: "The most important influence that the US can bring to bear upon internal developments in Russia will continue to be the influence of example". Kennan George, "America and the Russian Future", Foreign Affairs, April 1951, Vol. 29, n³, pp. 368. C'est nous qui soulignons.

7. . "The model (of Kissinger) for the conduct of international relations had simply ceased to work by the beginning of this century, not because of unskillful statecraft, but because the hermetic system in which it had been effective had ceased to exist". Voir Howard Michael, "Howard Michael, "The world according to Henry : from Metternich to me", Foreign Affairs, mai-juin 1995, Vol. 73, n³, p. 139.

8. . Plus que sur la pertinence du néoréalisme, le débat essentiel porte sur le niveau d'analyse en relations internationales. Sur ce point, Voir Singer David J., "The Level-ofAnalysis problem in International Relations", in Knorr Klaus et Sidney Verba, "The International System : Theoritical Essays", Princeton University Press, 1961, pp. 77-92 et Wendt A., "The Agent-Structure Problem in International Relation Theory", International Organization, Summer 1987, n³, pp. 333-370. En fait, "security dilemmas are not given by anarchy. If states find themselves in a self help system, this is because their practices made it that way. Far from being exogenously given, the intersubjective knowledge that constitutes competitive identities and interests is constructed every day by processes of social will formation". Wendt A., "Anarchy is what states makes of it : social construction of power politic", International Organization, Spring 1992, Vol. $46, n^{\circ} 2$, p. 407. C'est nous qui soulignons.

9. . "The realists reify the nation-state as a single idealised community acting to ensure its survival. It is in this mechanical notion of structure that the inherent weakness of Realism is most transparent. In order to conceive the state as a unit responding purely to the Balance of Power it must implicitly define it as ontologicallly anterior to the international system." Voir Ashley Richard K., "The Poverty of Neorealism", International Organization, Spring 1984, Vol. 38, n², pp. 225-286 et Buzan B., Jones C. et R. Little, "The logic of Anarchy : neorealism to structural realism", Columbia University Press, 1993.

10. . "While the realist perspective highlights the similarities between Charles V, Napoleon, Wilhelm II and Hitler by surimposing on widely constrating historical 
periods the logic of military competition in a state system, those same international struggles are mediating a wholesale transformation of the form and the conditions of social power in the world. We need a conception of historical agency as a disperced property of human societies which states organizations will always attempt to mobilize, but which is never reductible to state policy". Voir Rosenberg Justin, "What's the matter with Realism", Review of International Studies, October 1990, Vol. 16, n4, pp. 285-303. C'est nous qui soulignons.

11. L'argument selon lequel les Occidentaux ont voulu négocier avec les Soviétiques après avoir rétabli une "balance" stratégique ne résiste pas à une analyse approfondie. Pourquoi Moscou aurait-il consenti à négocier avec Washington en position de faiblesse ? D'autre part, les Européens ont toujours voulu traiter avec Moscou avant même le déploiement des euromissiles. Limiter les réformes intérieures de Gorbatchev à "an external imposed necessity", comme le fait Waltz, paraît bien une vue "irréaliste" des véritables forces en jeu au milieu des années 1980. "While western behavior was not irrelevant, it did not determine the outcome". Voir Risse-Kappen Thomas, "Did "peace through strength" end the cold War? : Lessons from INF", International Security, Summer 1991, Vol. 16, n¹, pp. 162-188.

12. . "A realist explanation that depicts Gorbatchev's radical reorientation of Soviet domestic and foreign policy as a response to the country's declining economy has difficulty accounting for the status quo under Brezhnev. Furthermore, it is very difficult to reconcile Soviet policy in Eastern Europe with realism." Voir Ned Lebow Richard, "The long peace, the end of the Cold war and the failure of realism", International Organization, Spring 1994, Vol. 48, n² 2, pp. 249-277.

13. . "If the Cold War was firmly rooted in "a structure determined by the distribution of capabilities", (Waltz K.), each side should have continued to focus its fears on the others, to distrust its motives and to impute offensive intentions to defensive measures. Ideas and ideology as interpreted in domestic politics seem chiefly reponsible for the dynamics of the Cold War, not the capabilities". Mueller John, "The Impact of Ideas on Grand Strategy", in Rosecrance Richard et Arthur A. Stein, "The Domestic Bases of Grand Strategy", Cornell university Press, 1993, p. 62.

14. . "States can no longer seek security at each other's expense, it can be attained only through cooperative undertakings. Security in the nuclear age means common security. The consequence that war can be no longer be won is that there is no reliable security against an opponent but only with an opponent. There is only common security and everybody is partner in it, not despite potential enmity, but because of this enmity.". Voir "Common Security : A programme for Disarmament", Palme Commission on Disarmament and Security Issues, pp. 138-139.

15. . Si les échanges d'idées sont essentiels, la structure des canaux par lesquels elles circulent, l'est tout autant. "The combination of a centralized decision-making structure with a reform-oriented leadership explains why the strategic prescriptions promoted by the transnational coalition had such a strong impact on Gorbatchev's foreign policy revolution in a short period of time. Once a channel into the top decision-making circle was open, the transnational coalition profoundly influenced policies". Voir Risse-Kappen Thomas, "Ideas do not float freely : transnational coalitions, domestic structures and the end of the Cold War", International Organization, Spring 1992, Vol. 48, n², p. 214. C'est nous qui soulignons. 16. . "The CSBM can be seen to operationalize the meaning of common security developped by the Palme Commission and to give expression to the notion of Europe as 
a common home. As an international regime, they can be classified as a pragmatic contribution to peacefully managing the classical "security dilemma" based on both the proscription of threat or use of force and the right to military self-defense". Voir Rittberger V., Efinger M. et M. Mendler, "Toward an East-West Security Regime : The Case of the CSBM", Journal of Peace Research, Vol. 27, n¹, 1990, p. 71.

17. . Pour une généralisation de l'argument, Voir Rosecrance Richard et Arthur A. Stein, "Beyond realism : the study of Grand Strategy", in Rosecrance Richard et Arthur A. Stein, "The Domestic Bases of Grand Strategy", Cornell university Press, 1993, pp. $1-22$.

18. . Contrairement à ce que croit Kissinger, la CSCE fit beaucoup plus que simplement "keep the issue of human rights alive". Kissinger Henry, "Diplomacy", op-cit., p. 793. 19. " "Stability in international relations also rests on the independent and democratic development of societies. Peace on our continent can only be secure if it is a really democratic peace, based on civil liberties and social justice and thus defended by all European citizens. A lasting peace can only be achieved by overcoming the various political, economic and social causes of aggression and violence in international relations as well as the internal conditions of states". Voir "For a Democratic Peace in Europe : a Memorandum to citizens, groups and governments of all CSCE countries", in East European Reporter, 1986, Vol. 2, n², pp. 52-59. C'est nous qui soulignons. 20. . "Emancipation and security are two sides of the same coin. Emancipation, not power and order, produces security". Booth Ken, "Security and Emancipation", Review of International Studies, October 1991, Vol. 17, n4, p. 319. Par conséquent, "the individuals represent the irreductible basic unit to which the concept of security can be applied". Sur ce point, Buzan Barry, "People, States and Fear : the Internatioanl Security Problem in International Relations", Wheatheaf, 1983, p. 10 et suiv. 21. . Par conséquent, "In contrast to the realist concept of the national political community, resistance writers, both East Europeans dissidents and West European Peace activists share the ideal of a non-territorial community based on the development of a trans-European civil society. Peace depends upon forging of a new internationalism, unmediated by states structures, between the citizenry of West and East". Voir Reus-Smit Christian, "Realist and Resistance Utopias : Community, Security and Political Action in the New Europe", Millenium, Spring 1992, Vol. 21, n¹, p. 18. 22. . L'un des conseillers de Baker eut cette remarque révélatrice : "Why buy what history is giving you for free ?". Cité par Beschloss Michael R. et Strobe Talbott, "At the Highest Levels : The Inside Story of the End of The Cold War", Little, Brown and Company, 1993, p. 20.

23. Selon la perspective réaliste, "the Cold War was not supposed to end as it did. In effect, the Cold War was not supposed to end at all". Steel Ronald, "The End and the Beginning", in Hogan Michael J., "The End of the Cold War : Its Meaning and its Implications", Cambridge University Press, 1992, p. 104.

24. . Canning avait exprimé cette idée de manière plus radicale : "Conferences are useless or dangerous : useless if we are in agreement, dangerous if we are not". Temperley Harold, "The Foreign Policy of Canning, 1822-1827", Cass, 1966, p. 135, cité par Jervis Robert, "From Balance to Concert : A Study of International Security Cooperation", World Politics, Octobre 1985, Vol. 38, n¹, p. 72.

25. . Sur la valeur de la paix démocratique, voir entre autres, Russett Bruce, "Grasping the Democratic Peace ; Principles for a Post-Cold War World", Princeton Univerity Press, 1993 et contra Layne Christopher, "Kant or Cant : The Myth of the Democratic 
Peace", International Security, Fall 1994, Vol. 19, n², pp. 5-49. Nous préférons quant à nous le concept de "communauté de sécurité", mis en lumière dès 1953 par Deutsch Karl, "Political Community at the International Level : Problems of Definition and Measurement", September 1953, Foreign Policy Analysis Series, Princeton Univerity, $\mathrm{n}^{\circ} 2$, pp. 1-25.

26. . "Social change did create a "new diplomacy" which had to take into account the broadened political base of modern states". Navari Cornelia, "The great illusion revisited : the international theory of Norman Angell", Review of International Studies, October 1989, Vol. 15, nº 4 , p. 357.

27. . "Today, there is a new trend, so messy that there is no adequate term for it. Democratization is not quite right, populism would be better. Maybe demands for "people power" or for "citizens" is the best approximation. It is popular demands and pressures that set much of the agenda of the government's foreign policies". Stanley Hoffmann, "Diffusion of Power in a Post-Cold War World", in Rubinstein Alvin Z., "America's National Interest in a Post-ColdWar World", Mc Graw-Hill, 1994, p. 30.

28. . "Statesmen must be judged not only by their actions but also by their conception of alternatives". Kissinger Henry, "A World restored", op-cit., p. 213.

29. . "In three and a half years, the very nature of the international system as we had known it was transformed. In this transformation, diplomats can and should take only modest credit. For the true responsability for the changes lies in the ordinary men and women who sought freedom, who struggled against the darkness of totalitarism, and who rose up to seize liberty of themselves". Baker James, "The Politics of Diplomacy", Putnam's Sons, 1995, p. 672.

\section{INDEX}

Index géographique : Etats-Unis

Mots-clés : diplomatie, politique étrangère 